Quelques eclaircissements épars sur mes Monumenta Cartographica Africae et Aegypti

Par Prince Youssouf Kamal. Pp. vi +216. (Leiden : E. J. Brill, S.-A., 1935.)

STUdents of the history of cartography in general, and of African cartography in particular, are deeply indebted to Prince Youssouf Kamal for the inception and production of his lavishly designed volumes"Monumenta Cartographica Africae et Aegypti"which he is presenting to all the important libraries of the world. When completed, this work will prove a valuable storehouse of cartographical material for students, to whom much of it would otherwise be inaccessible. Interpreting his title widely, he includes not only reproductions of original maps, but also reconstructions of the historical geography of various periods, and extracts from contemporary writers containing topographical references. The present volume is largely an explanation of the scheme upon which the "Monumenta" have been designed, and a commentary upon the material already published.

It is not a comprehensive history of cartography ; the author is content rather to discuss, without being didactic, and sometimes discursively, some of the major problems, and to indicate lines of profitable research. Such points are the symbolical character of early maps, the origin of the maps illustrating Ptolemy's Geography - he omits consideration of the probability that the tables of data were largely derived from maps of some kind-the content of medieval TO maps, and the work of the Oriental or Arab cartographers. His analysis of the latter reinforces the evidence for their dependence upon classical sources. In discussing his plan for the final volume dealing with the European discoverers of the early modern age, he presents a useful summary of the cartographic evidence for maritime activity along the coasts of north-west Africa prior to the movement associated with the name of Prince Henry. It yet remains to be demonstrated by whom this work was performed, and the relative contributions of Portuguese, Spanish and Italian pioneers. It is evident that this formidable undertaking is the work of a true enthusiast, and a patron of research.

G. R. C.

\section{Fundamentals in Teaching Home Economics}

By Ivol Spafford. Pp. xiii +424 . (New York : John Wiley and Sons, Inc. ; London : Chapman and Hall, Ltd., 1935.) 13s. 6d. net.

Few students of social problems to-day will question the general statement that the strength and sanctity of home life is still one of the most vital elements in the national fabric; and that the efforts now being made by far-sighted educationists to place the study of home economics on a firm basis, occupying a high and secure position in school curricula, merit every encouragement. This need was well recognised by the inclusion in the recent Congress for Scientific Management of a section for domestic economy; and in the present excellent and comprehensive work that need is still more clearly and fundamentally emphasised and provided for. The book deals of course with the teaching of home economics in the United States, but its breadth of view and depth of thought are such as to make it international in scope and application.

Home economies is here seen to be a matter of deep interest to everybody, to all indeed who have or hope to have any sort of home life and wish to make the best of it in all its varied intellectual, practical and emotional aspects. It is something vastly greater than a cookery or sewing class for adolescent girls. It makes a stirring appeal to boys and to adults of both sexes. It reaches down to the fundamentals of education in its analysis of the desire to learn, to know the truth, of thinking and selfdirected education, of measuring progress in learning, and of the philosophy of education in general. But besides these deeper general aspects of the subject, the book contains a wealth of practical and helpful instruction to the teacher in a very difficult field, based on the author's own wide experience and profound study which, judging from the copious list of references appended to each chapter, must have been of an unusually complete and indefatigable nature.

\section{Sumatra}

Its History and People, by Edwin M. Loeb; The Archaeology and Art of Sumatra, by Robert Heine. Geldern. (Vol. 3 of Wiener Beitrage zur Kulturgeschichte und Linguistik des Institutes für Völkerkunde der Universität Wien.) Pp. ix $+350+40$ plates. (Wien : Verlag des Institutes für Volkerkunde der Universität, 1935.) 23 Osterr. schillings ; 4.40 dollars.

Although both the authors of this volume have a first-hand knowledge of the indigenous peoples of the Dutch East Indies, they do not claim to have attempted more than compilation. The result of their labour is, nevertheless, welcome to English readers, among whom a knowledge of the Dutch language, in which the copious literature dealing with the antiquities, culture and peoples of these islands for the most part has appeared, is either non-existent or far from profound. A reference to the extensive bibliography of the works upon which they have drawn for their material will show how very extensive this literature has come to be. To a great extent, the bar of language has been responsible for the fact that the position of the Javanese in the ethnology of Indonesia and as a link extending from New Guinea to the Malay Peninsula has received less consideration than its importance warrants.

In the section dealing with art and archæology, the author distinguishes no less than ten cultural strata extending in date from palæolithic (here a cultural rather than a chronological term in the strict sense) to the Chinese influence of the end of the fourteenth century A.D. It is to be noted that in the palæolithic he discriminates between a flake culture, which he holds to be probably Veddoid, and a hand-axe culture, which he would assign to the Papuo-Melanesian.

The book is illustrated by excellent photographs. 